\title{
Praxis and the ends of action in Suárez
}

Praxis y fines en Suárez

DAVID GONZÁLEZ GINOCCHIO

University of South Bohemia

Universidad Internacional de La Rioja

Escuela de Humanidades

26006 Logroño (España)

dgginocchio@gmail.com

Abstract:I will try to show how Suárez's model of praxis allows for the coordination of intellect and will to generate actions through the integration of ends. A special sense of causality is studied that adds a practical overlay to actions: while actions remain an external mode of the effect, they can be contingent insofar as they are produced by a free agent with particular ends in mind. I will argue that the appearance of these ends is only possible through a habitual understanding of praxis, which is a subjective consideration of reality as 'operable'.

Keywords: Francisco Suárez, praxis, human action, ends.
Resumen: Intentaré mostrar cómo el modelo de praxis de Suárez permite la coordinación de intelecto y voluntad para generar acciones mediante la incorporación de fines. Se estudia un sentido especial de causalidad que añade a las acciones un revestimiento práctico: al tiempo que las acciones siguen siendo un modo del efecto, pueden ser contingentes en la medida en que están producidas por un agente libre con fines concretos en mente. Argumentaré que la aparición de estos fines solamente es posible mediante una comprensión habitual de la praxis, que es una consideración subjetiva de la realidad en cuanto 'operable'.

Palabras clave: Francisco Suárez, praxis, acción humana, fines. 
will deal in this paper with the problem of the difference between natural and human actions, and how the latter are the product of the specific kind of intellection provided by the habitual sense of praxis, which allows for human actions to be free and directed towards ends. I will proceed by, first, presenting the 'instinct-based' action circuit, i.e. the way in which animals move according to the internal sense and whether this can be said to be a movement directed towards an end $(\$ 1)$. I will then consider the introduction of intellectually-determined ends of actions, first in Aquinas and Scotus $(\$ 2)$, and then in Suárez (\$3). I will finally seek to point out exactly how they are introduced by showing how the operational sense of praxis actually constitutes agents as such $(\$ 4)$.

\section{MOVING TOWARDS AN END IN A GENERAL SENSE}

In this first section I will describe a general theory of action, applicable to both animals and human beings, as the basic framework on which praxis is built upon. Indeed, praxis is a specific kind of human acting that consists on the 'addition' of the intellect and the will, with the former specifying and the latter efficiently exercising it. Now, in order for praxis to be conveniently understood, what I call the 'general circuit of action' may be dealt with here first. The broad form of this circuit, as employed by authors like Aquinas, Scotus, and Suárez, was basically described by Aristotle in De motu animalium, 7. In Aristotle's account (cfr. Bk 701b 1ff), animal movement may be compared to the motion of automatic puppets, controlled by levers and similar contraptions, or by the way boys move their toy wagons. Animal bodies have similar parts: organs, bones like levers, string-like sinews, etc. Thus, like in natural events, animal movement begins with a change of quality: parts of their bodies get warmer or colder, augmenting or contracting and bringing, through these shifts, the movement of bones and limbs. The change of quality itself is due to "imaginations and sensations and ideas". Movement begins with small changes in the center, which then provokes bigger changes in the circumference.

According to C. Rapp, there is no 'translation' of desire from a pneumatic plane to the material one of kinetic action. Rather, 
[...] in accordance with what I take to be an implication of Aristotle's 'hylomorphic' theory of the soul and with what I take to be the most unforced reading of the De Motu Animalium, it is not the case that desire somehow acts upon the body and that the body is altered accordingly; rather I take it that desire itself consists in a characteristic bodily change or rather sequence of bodily changes, which starts with the chilling and eating that takes place if we see or judge something to be pleasant or painful, to be pursued or to be avoided, leads to extension and contraction of some inner parts of the body and finally makes the limbs and then the entire animal move. ${ }^{1}$

It is also in De motu that Aristotle compares movement to a logic inference. In a syllogism, "the end is the truth seen (for, when one conceives the two premises, one at once conceives and comprehends the conclusion), but here the two premises result in a conclusion which is an action". ${ }^{2}$ Hence we obtain, in a 'practical syllogism', an (a) apprehensive or cognitive premise -in this text represented as 'sensations, imaginations and ideas'-, and (b) a desiderative premise.

We could perhaps conclude then that Aristotle holds a "Humean model" of practical reasoning, which also affirms that a desiderative premise and a cognitive premise must unite in order to produce action. However, in the Humean model,

[...] our ends are given by passions (desires). On this view, reason is in the business of producing beliefs, but our beliefs are relevant only to the means by which we seek to obtain those ends: they do not determine the ends themselves. So, reason has only an instrumental use. ${ }^{3}$

1. C. RapP, Tackling Aristotle's Notion of the Will, "Philosophical Inquiry" 41/

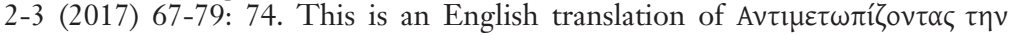

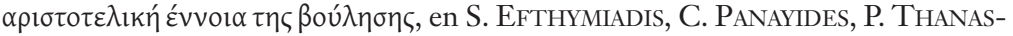
SAS (eds.), Readings of Aristotle (Nicosia University Press, Nicosia, 2014) 51-69, which can be found on his Academia profile (http://bit.ly/1le0Bgc) (Last access 23.XI.2015).

2. ARISTOTLE, De motu animalium, 7, Bk 701a 11-12.

3. A. M. SchmitTer, Hume on the Emotions, en E. N. ZalTa (ed.), The Stanford En- 
In the Aristotelian framework, the cognitive clause is not just instrumental but, as we shall see, determining - more so in human action, in which we actually determine the end as the specifically differential element of praxis. The desiderative dimension can only be surmised according to the range provided by the cognitive one: we can only desire that which we know, insofar as we know it. This point is important in that it will later ground discussions about the specification of human actions and in the possibility of wishing "false" goods, i.e. apparent, or between different possible goods.

This Aristotelian model applies in an analogous and general sense to the movement of both animals and humans. In Aristotle, this generality makes sense insofar as he doesn't have a clear conception of a 'rational appetite' or will. Thus, in both humans and animals

[...] desire, be it rational or not, plays a similar role for the self-movement or locomotion of animals. In De Motu and in De Anima Aristotle gives us a model according to which movement is initiated by the collaboration of two faculties or two families of faculties: the desiderative ones (epithymia, thymos, boulêsis) and the discriminative ones, sensual perception, phantasia and nous (thinking). ${ }^{4}$

The three forms of desire are of course a Platonic heritage, and specifically boulêsis will later on serve to treat human action in greater detail:

Boulêsis [is] rational desire or the type of desiring that is connected with reason. Boulêsis or wish, as we may translate it, is directed towards the good and is responsive to reason. The intellectual and cognitive effort connected with wish is much greater than the one connected with non-rational desire, hence

cyclopedia of Philosophy (Winter 2012 Edition) <http://plato.stanford.edu/entries/ emotions-17th18th/LD8Hume.html> (Last access: 24.XI.2015).

4. C. RAPP, op. cit., 73. 
Aristotle is explicit about the point that only human beings can have wish. It follows that Aristotle wants wish to be an essentially rational form of desiring. ${ }^{5}$

Suárez also allows for a general treatment of action common to both humans and animals. The reason is that action can be determined from a categorical point of view. Within this approach, all actions are ontologically the same: a relational mode of the caused being that relates to its cause. ${ }^{6}$ Both animal and human actions, in this sense, can be understood as efficient causality, and therefore, externally, not really different from other natural movements. The differential point resides in the mode of an action. Human actions are contingent because they are voluntary, i.e. free. Still, both kinds of actions can examined not from a natural point of view, but from a psychology of action framework. Let me turn now to the way in which animal actions incorporate ends, and then I will try to show how praxis differs in this respect, and how the habitual features of praxis allow for the free, contingent mode proper of human actions.

According to Suárez, animal movement follows the object of the internal sense. In his Metaphysical Disputation XXIII, section X, he states that in order for us to be able to claim that animals move themselves because of a final cause, they should be aware of a proper order that connects means to ends, an awareness that requires the intellect and the will. ${ }^{7}$ Animals cannot be said to be move themselves by a final cause, even if they are directed "towards and end and are themselves effects of a final cause." ${ }^{8} \mathrm{We}$ may even speak of a "metaphorical sense of prudence" in animals, because they are

5. Ibidem.

6. For the Suarezian view of action as a category, cfr. M. LECón, Metaphysics and Psychology of the Making of Law in Francisco Suárez, en K. Bunge, M. FuCHS, D. Simmermacher (eds.), The Concept of Law (lex) in the Moral and Political Thought of the 'School of Salamanca' (Brill, Leiden, 2016) 249-270.

7. F. SUÁREZ, DM 23.10.1.

8. F. SuÁreZ, DM 23.10.6. 
[...] metaphorically attracted (metaphorice alliciuntur) by a good that is convenient and known to them (a bono sibi conveniente et cognito); in this way they tend towards it by an act produced by them and caused by this metaphorical motion; therefore, such a motion is a real causality and this can be no other than final. ${ }^{9}$

The expression "metaphorically attracted" is not restricted to animals: it reappears in Suárez's Commentary on the De anima referring to human action. For animals, the key is that their acts are caused by a final cause, but they are not themselves the principle of the final cause (the archê is not within them, in Aristotelian terms). Thus, they move towards an end they know as convenient and appealing, but not as good, for, according to Suárez, knowing the ratio of good is a feature of the intellect.

The concept of good as such involves an ability to relate it to our own nature, i.e. we have the sense of why it is $a$ good, and a proximate or remote one at that. Animals

[...] do not know the ratio of end or mean, because they cannot compare (conferre) one to the other; therefore, not even in the end itself do they know the reason of convenience, by virtue of which [the object] is lovable by itself. Furthermore, they cannot discern whether the object is convenient by itself or by another. [...] And yet they still know in a certain fashion and they apprehend a certain thing or motion as convenient to them, and with a natural instinct they judge they must appetize such an object, or go after it, or run from it. ${ }^{10}$

This means of course that their perception of good is limited to the internal sense. And to this internal sense "the natural appetite is no different than the nature or natural faculty: it accompanies it in a quasi-formal way, or as a natural consequence. The elicit appetite, however, is quite different". ${ }^{11}$

9. F. SUÁREZ, DM 23.10.12.

10. F. SUÁREZ, DM 23.1.14.

11. F. SUÁREZ, DM 23.7.5. 
We should thus acknowledge that the natural or simple circuit of action is wholly grounded on the imaginative faculty's cognitive power:

Animals know and apprehend some thing or some motion as convenient to them. And by the natural instinct they judge it as convenient for them, they appetize it, they follow it, or they flee from such an object. This natural instinct is no other than a certain act of the phantasia or the estimative faculty, naturally necessitated by it when the phantasm of a certain thing is put forth; and by this practical act (according to the human way of speaking) the brutes judge something to be avoided or persecuted, or appetized, insofar as they are unable to rationally discern the reason of convenience or inconvenience. And when this natural judgement is put forth, so too the appetite follows. ${ }^{12}$

The limits or animal action are set by the formality of the internal sense's cognition: that is why animals cannot apprehend the ratio of good, end, means, or the order between them. ${ }^{13}$ In animal actions, the external senses' objects are unified in the internal sense in such a way that they excite the animal's appetites. ${ }^{14}$

But Suárez also emphasizes two points: first, he is careful here when attributing cognitive powers to the senses, for it is easy to confuse intelligible and merely sensible functions: "as the sense is always accompanied by the intellect, when the intellects reasons (discurrit) around different places and times, the sense goes with it" (DA 8.1.12). Second, he is clear that the internal sense cannot receive any species from the external sense, even if it is dependent on the external senses' actions - just as the agent intellect is dependent on the internal sense's action and yet the latter cannot direct move the

\section{F. SUÁREZ, DM 23.10.14.}

13. Suárez reduces the internal senses to a single one, but I will omit that argument here. For this matter, see the detailed treatment in DA 8.1 and J. B. SouTH, Francisco Suárez on Imagination, "Vivarium" 39/1 (2001) 119-158.

14. See F. SuÁrez, DA 8.1.9. 
act of the former (i.e. the phantasm is not the efficient cause of the agent intellect's act). ${ }^{15}$ It is clear, then, that animal actions cannot incorporate a rational conception of good nor can they determine any act of the will.

How then are the rational powers introduced in the circuit of actions? By overlaying a conception of beings as goods, i.e. by the introduction of bonum over mere entity.

\section{AQUINAS AND SCOTUS ON THE INTELLECT AND THE WILL ${ }^{16}$}

According to Aristotle, human actions require boúlesis (rational desire). ${ }^{17}$ The reasoned action (praxis) thus includes both an intellectually conceived good which provides the focus of this desire, and the will as a rational appetite. While animals have no freedom, perceive goods/ends according to their senses' reach, and pursue them to the best of their ability until they acquire it or realize it is out of reach; human beings, on the other hand, can intend goodness beyond the perceptual plane, and can freely initiate an action - or not - towards one end or another. (They can move towards misconceived ideas of goodness.) Here both the cognitive and the desiderative components demand an ampler perspective. Reason must be able to present an object as good in a sense that 'moves' beyond the sensual desire, namely the will, which is capable of selfdetermination.

But even if Aristotle claims human action requires boulêsis, he did not seem to have a notion of the "will" as a rational potency; ${ }^{18}$

15. See F. SUÁREZ, DA 9.2.12. The main point here is a sharp distinction between the intellect's cognitive powers and those of the senses. Suárez "in effect blocks every attempt Thomas makes to enhance the power of the internal sense, reserving those extended powers to the intellect. The cogitative power is denied, accordingly, any transitional role in the process of cognition" (J. B. SOUTH, Francisco Suárez on Imagination cit., 136).

16. In this section I shall lean on Th. M. OsBorNE, Jr's recent systematic study, Human Action in Thomas Aquinas, John Duns Scotus and William of Ockham (The Catholic University of America Press, Washington, D. C., 2014).

17. Cfr. C. RapP, op. cit., 73. Rapp notes that Cicero rendered boúlesis as voluntas in Latin, and Aquinas equalized it with appetitus rationalis.

18. Following Ch. Kahn, Rapp notes that Aristotle indeed considers four instances of 
Scholastics, on the other hand, possessed a wide array of technical terms and models to color probairesis. The process involved, broadly speaking, a detailed account of what the intellect brings as the cognitive component of action, what the will brings, and the way in which these two superior faculties relate to each other, thus mapping the "moments" in the genesis of human action. Two of the greatest medieval authorities, Aquinas and Scotus, developed such an account - though from different perspectives and with similar but not equal questions in mind-; Suárez's position, as usual, aims to maintain a careful balance between them. The nuanced positions of these authors should at least make us wary of easily-applied labels, such as "intellectualist" and "voluntarist". As Aquinas and Scotus's positions provide the great framework for Suárez, I will delineate their positions first and then (\$3) look into his doctrine.

For Aquinas, human freedom rests on the intellect insofar as only the intellect can know the ratio of the end and how actions can be ordered towards it. ${ }^{19}$

First, the indetermination of free choice results from the intellectual agent's ability to know different goods in a way that is not determined by material conditions. Second, this indetermination allows for reflection on how ends are instantiated in or achieved by means of different acts. Third, the movement to the good is controlled by the will, which moves not only the intellect but also the other powers of the soul. ${ }^{20}$

rational agency —an action that is up to us (eph' hêmin), an action that is voluntary (bekousion), a sense of things that are chosen, and thus result from probairesis, and the desiderative element boulêsis-, and yet lacks a unifying concept for all of them, let alone a systematically unifying faculty. Thus, "[In the Nichomachean and Eudemian Ethics] Aristotle's treatment of the voluntary amounts to the following thesis: external force and non-culpable ignorance make actions involuntary, and 'voluntary' is just the opposite of 'involuntary'. (...) In one respect, it seems to me, Aristotle nevertheless goes beyond the discussion of excuses - this is when he attempts to give a general definition of the voluntary. Things are done voluntarily or of our own accord, if the archê, the origin of these doings is in us. (...) Later probairesis will be called the archê of actions" (Ibidem, 74).

19. Cfr. Thomas Aquinas, II Sent d25 q1 a1, c.

20. TH. M. Osborne, op. cit., 8. 
The human will is naturally directed towards the final end, happiness, but free agents must choose their particular way to achieve it, as no direct good appetized by the will is simply equivalent to happiness.

Aquinas distinguishes two senses of freedom: of exercise and of specification. Freedom of exercise depends only on the will; freedom of specification consists in the intellect's determining the object of an action. Both senses concur in the action, but each can be highlighted to remark the proper place of each faculty. Thus, insofar as the ratio of "goodness" is specified by the intellect, then

if some object that is good universally and from every point of view is proposed to the will, out of necessity the will tends to it, if it wills anything, for it cannot will the opposite. If however some object is presented to it that is not good from every point of view, the will does not respond to it out of necessity (non ex necessitate fertur in illud). [...] All other particular goods [aside from the perfect good], insofar as they are lacking some good, can be regarded as 'not good,' and from this point of view they can be assented to or rejected by the will, which can respond to the same thing according to diverse points of view. ${ }^{21}$

Here we should note, along with Thomas Williams:

Interpreters disagree sharply over whether Aquinas thinks the will has any power of its own to shape human action or (to put the matter in different terms) whether there is any freedom or indeterminacy in human volition that is not traceable to the intellect. [...] Even a small detail like the translation of fertur as $<$ respond $>$ in the following quotation from ST I-II 10.2 is telling here. [...] 'Respond' is active: the will does something, or doesn't do something, on its own steam, as it were. But fertur is passive. If we translate accordingly — "the will is not drawn

21. Thomas Aquinas, STh I-II q10 a2, c., quoted in Th. M. Osborne, op. cit., 11-12, trans. Th. Gilby, Summa theologiae vol. 17 (Cambridge University Press, 1964). 
to it out of necessity" - the picture is that the will is carried along, or not carried along, to an object depending entirely on how the intellect judges it. ${ }^{22}$

How the will is carried along, at any rate, depends on the ratio of good as specified by the intellect. It seems then that only an absolute good would "necessitate" the will to act in an unqualified sense, in the sense that the natural inclination of the will towards good and the specification of an absolute Good would coincide. It is unclear whether this determination relates only to freedom of specification or if it's also meant for the will's freedom of exercise - which, in any other case, is of course only dependent on the will itself. Still, it is a commonly held thesis that the will is also able to move the cognitive potencies, so in a sense the will can lead the intellect to a different consideration of something as good, or to a different object altogether. ${ }^{23}$

These margins are important because they lead the theory of the four causes into the explanation. Indeed, Aquinas himself seems to identify freedom of exercise with an efficient sense of causality (wholly dependent on the will) and freedom of specification with a final sense of causality (dependent on the intellect). The introduction of causal explanatory senses is relevant, for it allows a common language of dialogue with Scotus and Suárez.

Scotus will also identify the intellect's object with the efficient cause of actions, but not absolutely. Thomas stresses much more forcefully the intellect's capacity to present different rationes of goodness. For Scotus, the process seems more straightforward, as his consideration employs a different perspective from Aquinas, namely by adopting the idea of the two so-called affections of the

22. Th. Williams, Review of Thomas M. Osborne 7r., Human Action..., "Notre Dame Philosophical Reviews", 16.VII.2014 (http://ntrda.me/1lfHeTQ). [Last access 23.XI.2015.]

23. Thomas Aquinas, SCG I.72: "voluntas omnem potentiam applicat ad suum actum; intelligimus enim quia volumus, et imaginamur quia volumus, et sic de aliis. Et hoc habet quia obiectum eius est finis: —quamvis intellectus non secundum modum causae efficientis et moventis, sed secundum modum causae finalis, moveat voluntatem, propenendo sibi suum obiectum, quod est finis". 
will, taken from St. Anselm: the affectio commodi - i.e. the will's movement towards good in a natural sense as an appetizing rational faculty-, and the affectio iustitiae - i.e. the formal consideration of the will as a free faculty. ${ }^{24}$

As Thomas Osborne observes:

For Thomas, the ability to choose between different actions is rooted in the intellect's ability to think about different possible goods. In contrast, the distinction between the good in general and particular goods does not play the pivotal role in Scotus's account. Scotus thinks that the intellect could grasp the good and be determined to it. There are different possibilities precisely because the will can choose between two options, namely the advantageous and the just. The very possibility of an intellectual but not free creature shows that for Scotus freedom is rooted not in the intellect but in the will as a rational potency with two distinct inclinations. ${ }^{25}$

The intellect of course presents different goods, but the critical factor here seems to be the will's following of a determination towards that which is pleasant, or that which is seen as just.

From a purely logical point of view, freedom in Scotus depends absolutely on the will due to its capacity for self-determination. ${ }^{26}$ Scotus seems to emphasize 'freedom of exercise' to a greater degree than Aquinas, following his idea that the will retains the power to will the opposite of an act in the same instant as it is willing it (a feature scholars commonly define as synchronic contingency). ${ }^{27}$ So, for Scotus, we "do not call something contingent because it is not

24. Cfr. C. González Ayesta, Duns Scotus on the Natural Will, "Vivarium" 50 (2012) 33-52.

25. Th. M. OsBorne, op. cit., 27.

26. See E. STump, Obligations: From the Beginning to the Early Fourteenth Century, en N. Kretzmann et al. (eds.), The Cambridge History of Later Medieval Philosophy (Cambridge University Press, Cambridge, 1982), ch. 16, Part A, 315-334.

27. Cfr. S. Dumont, The Origin of Scotus's Theory of Synchronic Contingency, "Modern Schoolman" 72 (1995) 149-167. 
always or necessarily the case, but because its opposite could be actual at the very moment when it occurs." 28

Scotus's more radical defense of the will as the formal cause of freedom entails the clarification that the intellect's ability to think about different possible goods is not enough to formally speak of freedom (following the fictional account of Anselm's De casu diaboli, Scotus argues that a created intellect moved only by the affectio commodi would be able to think about different goods, and yet their choices would not be free). The affectio iustitiae is the proper per se cause of freedom. ${ }^{29}$

Still, Scotus is also bound to hold that the intellect specifies action in the sense of an efficient cause, because without an object the will would be blind. ${ }^{30}$ Thus,

[...] in the Lectura, Scotus takes a middle view between two positions. The first one claims that the cause of the will's activity is the known object, and the second is that the known object is merely a cause that is sine qua non. The first position was held in different ways by Godfrey of Fontaines and others, whereas the second was held by Henry of Ghent and many in the Franciscan tradition. ${ }^{31}$

Scotus will argue that the object is a partial efficient cause or cocause of action, while the will is the principal efficient cause.

On his Paris reportationes there is a change in terminology, even if his basic position seems to remain the same. Scotus now defends the will as the total determining efficient cause of the act, but he seems to adopt Henry's terminology and claims the object can be understood as a sine qua non cause in the sense of a partial efficient cause, which amounts to considering it an efficient cause per accidens. On the later Ordinatio IV he seems to endorse both possibilities. At any rate, he always claimed that the will is the total efficient cause.

28. Duns Scotus, Ord I d2 $1^{\text {a }}$, qq1-2, 86 .

29. Duns Scotus, Lectura II d25, 33 .

30. Duns Scotus, Lectura II d25, 78: “...liberum arbitrium esset caecum”.

31. Th. M. OsBorne, op. cit., 32. 
He considers the possibility that the object moves metaphorically as a final and not efficient cause, but he does not endorse the position.

I believe all these positions merely amount to one of his rules for essential order: it is possible for A to cause B but only after C. In this case, it is possible for the will to be the total efficient cause of a volition but only after the intellect has determined the mind towards a concrete good.

\section{SUÁREZ’S NOTION OF PRAXIS}

Final causality is actually the sense Suárez assigns to the intellectual component of action: it is precisely the object presented by the intellect as a convenient good the one that specifies human action. Thus, the object is required by the act, and yet it does not take anything away from the will's freedom of exercise, i.e. from the will as the total per se efficient cause. ${ }^{32}$

Suárez carefully distinguishes sensible and intellectual knowledge:

There is a great difference between sense and intellect because sense stops at (sistere) the cognition of sensible external accidents. Intellect, however, does not stop there but from the cognition of accidents it advances to contemplating those realities that are concealed (latere) under the accidents. And therefore it is called 'intellect' as from 'reading within'.33

In this sense, it acts as a final cause for the will's action. So, while necessary and determinant for the will's movement, the object is not, strictly speaking, the efficient cause. "And the reason of this

32. On the distinction between these two senses of causality and the distinction between the motivation and the self-determination of the agent cfr. T. PINK, Suarez, Hobbes and the scholastic tradition in action theory, en T. PINK, M. STONE (eds.), The Will and Human Action: From Antiquity to the Present Day (Routledge, London, 2004) $127-153$.

33. F. SUÁREZ, DA 9.4.1. 
is that final causality consists in a metaphorical motion of the will, which is enticed towards it". ${ }^{34}$

The metaphorical motion of the will is precisely the object from the viewpoint of final causality. Thus, as Sidney Penner writes:

In order for the will to be attracted to an end, the intellect must cognize the end and present it to the will. Since the intellect can think about things that do not exist, the intellect can present objects that currently exist only in the mind to the will. This is why final causes, unlike efficient causes, do not need real existence in order to cause. This does not mean, however, that the final cause in truth is the mental entity. [...] But once the intellect presents a good object - really existing or not, genuinely good or not- to the will, that object is attractive to the will. The will can then produce an act of love for the object. Assuming that the will does so, there is an instance of actualized final causality. ${ }^{35}$

Suárez presents this motion as a holistic unified process, which can only analytically understand efficient and final causality as separated components:

One and the same action of the will is caused by the end and by the will itself. It is effective causality insofar as it is caused by the will and it is final causality insofar as it is caused by the end. And for the former reason it is a real and proper motion, because such an action flows from the power as from a proper physical principle, but for the latter reason it is a metaphorical motion, because it flows from an object enticing and drawing the will to itself. ${ }^{36}$

34. F. SUÁREZ, DM 23.5.2.

35. S. Penner, "Final Causality: Suárez on the Priority of Final Causation" cit., 129. 36. F. SUÁREZ, DM 23.4.7. 
We need not take "metaphorical motion" as if it were an apparent, false, or merely hypothetical motion. Following Penner, it can be cautiously assumed to be a technical term relating to the difference between efficient motion and the kind of motion specific to the final cause. The final cause is a non-physical way of moving. We speak then of an analogical motion, that does not directly relate to the notiora idea of motion as we directly attest in nature as an efficient cause, so that even if this motion

[...] is called metaphorical, [it is] not because it is not real, but because it does not happen through effective influx nor through physical motion but through intentional and animal motion. And therefore nothing prevents it from being the case that its causality is true and proper. ${ }^{37}$

It can readily be seen that proper refers here to efficient causality insofar as it resembles a proper physical principle; we've seen that, in terms of its categorical determination, all actions are natural movements. 'Free' is just a mode of some of these actions. Therefore free actions are natural actions, but ones whose efficiency begins with the will. As 'action' is a mode of the effect, it is no less an action than any other, even if its mode is called 'contingent' because its source is the will.

In this action model, final causality as the origin of actions exists properly only in rational agents. Animals do not choose their ends, even if they cognize it as somehow desirable; natural beings are involved in no appetizing whatsoever: their actions are just so modelled that their form elicits efficient activity as directed towards a pre-defined goal. What changes then is not action as something real, but the mode of action as a relation to its source potency. Suárez expresses this by saying that natural agents are "habituated" towards a final cause, but they are not themselves properly con-

37. F. SuÁREZ, DM 23.1.14; cfr. S. PENNER, op. cit., 135. It can readily be seen that proper refers here to efficient causality insofar as it resembles a proper physical principle; we've seen that, in terms of its categorical determination, all actions are natural movements. 'Free' is just a mode of some of these actions. 
cerned with a final cause ("a naturalibus agentibus non sit propria causalitas finalis, sed solum habitudo ad certum terminum": DM 23.10.6). Their actions are moved according to final causalities as externally caused by God. ${ }^{38}$

How are the intellect and the will ordered in the production of external actions? According to Suárez, the intellect provides a rule for the will, and the will is the principle of exercise insofar as it is self-determined. ${ }^{39}$

a) The intellect is the rule of the will following its capacity to apprehend the ratio of good —an exclusive feature of rational agents. As the intellect grounds the openness to opposites ("objective indifference"), the will's own indifference towards them, which allows it to freely self-determine itself, depends on the intellect. The intellect's objective indifference means that

[the intellect] suggests different rationes of convenience and inconvenience, and in a similar manner doesn't always suggests a means as necessary but as indifferent, insofar as besides discerning its degree of utility and difficulty, at the same time it discovers or suggests other means; that is why it is the fundament of the will's free choice. ${ }^{40}$

Suárez therefore considers reason as the "root of freedom", even if the formal ratio of freedom is in the will. ${ }^{41}$ Suárez believes this is in line even with Scotus's radical defense of the freedom of the will, and when Duns speaks of the intellect as a necessary condition for freedom, not as root, this is "because he worries more about the way of speaking than about the doctrine." 42 This entails that the intellect

38. Cfr. F. SuÁREZ, DM 23.10.6.

39. Cfr. A. Vigo, Intelecto, deseo y acción en Francisco Suárez, en J. Cruz (ed.), Razón práctica y derecho. Cuestiones filosófico-jurídicas en el Siglo de Oro español (Eunsa, Pamplona, 2011) 15-23.

40. F. SUÁREZ, DM 19.5.22.

41. F. SuÁrez, DM 19.5.11-20. See also J.-P. Coujou, Causalité libre et moralité de l'action chez Suárez, en C. González Ayesta, R. LÁZARO (eds.), Causality in Early Modern Philosophy (Georg Olms Verlag, Hildesheim, 2013) 89-98.

42. F. SuÁrEZ, DM 19.5.21. 
is not formally free; ${ }^{43}$ still, "this does not work against the intellect's perfection, which in absolute terms consists in being the rule of the will". ${ }^{44}$ Indeed, Suárez holds that as rule of the will the intellect cannot be free, for rules must be certain and immutable, and not inclined towards the matter of regulation, but rather adequate themselves to it in a determinate way. ${ }^{45}$ The will, on its part, is blind without its rule. For Suárez, "no potency whose act is not intrinsically voluntary can be formally free according to exercise." "46 Suárez is here following Scotus: natural agents as those whose active potency elicits their act in presence of their object (passo approximate) if there is no impediment: "the intellect cannot be in any way indeterminate towards its object if not because an imperfect presentation of the object. The will, on the other hand, even before an object exactly presented to it, can remain indifferent." 47 Still, Suárez holds that the intellect's indifference means that in an absolute sense the intellect is more perfect than the will because it is more simple and abstract.

b) In DM 23.4.7 Suárez allows for a double consideration of action: while it can be considered according to final causality as moved by the end (the object presented by the intellect), it can also be appreciated according to efficient causality as the will's act. The understanding of action according to efficient causality depends on the will as a self-determining principle, a complex doctrine Suárez explores at length in the De voluntario et involuntario. We may briefly relate here that the will's self-determination is possible because every elicit act includes a virtual, reflexive "sub-act" that allows the will to choose an object according to the mode of the act and not to the mode of the object. ${ }^{48}$ This means that the will can freely

\section{Cfr. F. SuÁREZ, DM 19.5.24.}

44. F. SuÁREZ, DM 19.5.25.

45. This is repeated in DM 19.5.13: "The intellect is not free neither in the specification nor in the exercise of its act"; "it is determined by its nature to assent to truth and to dissent to falseness; and if the object presents neither of these rationes, or the intellect is incapable of grasping them, it cannot realize any act because it cannot act without its object."

46. F. SUÁREZ, DM 19.5.17.

47. F. SUÁREZ, DM 19.5.15.

48. F. SuÁREZ, De voluntario et involuntario 1.1.2. And in 1.1. 6: "esse voluntarium in actu elicito, nihil aliud esse quem esse actum, ita immediate manentem a volun- 
determine itself towards an object only because it determines itself as determined towards that object. According to Suárez, animals are unable to be subjects of the law because they cannot self-determine themselves and thus their will cannot be normatively determined. ${ }^{49}$

In sum: by understanding the object as a final cause and presenting an ordered view of the part played by the intellect and the will, Suárez seems to have acknowledged both Aquinas and Scotus's positions, upholding their main thesis (the act is only exercised by the will, but the will's act needs an object to direct it) without undermining their particular roles. The intellect provides a rule that the will can intend; this rule acts as a metaphorical end that the will may achieve by employing its dominion over the bodily faculties. The rule provided by the intellect is an object seen as adequate to our human nature: this adequation is what the will perceives as good. Praxis hinges on the intellect's view, for "according to the way in which the intellect perceives everything in its own degree of goodness or malice, so can the will love according to that degree of goodness." ${ }^{50}$ This whole complex operation is what Suárez calls praxis, the first habit of the practical intellect.

Regarding transcendental goodness, Suárez is careful to defend that it identifies with a being's proper perfection, and is not primo per se a relational feature. Suárez argues against bonum being a "relation of convenience", a "real relation superaddita to a being", a "certain absolute and real property", or "a real intrinsic perfection"; ${ }^{51}$ he rather argues that bonum "only adds to being a ratio of convenience which is not a proper relation, but only connotes in another a nature to which it has a natural inclination, capacity, or connection with such a perfection. Therefore, bonitas is said of the same perfection of the thing." ${ }^{52}$ This openness of perfection is what allows the intel-

tate, ut per se ipsum intrinsece sit volitus per virtualem et intrinsecam reflexionem in ipso inclusam".

49. F. SuÁrEZ, De legibus I, I, 2: "res carentes ratione non sunt proprie capaces legis, sicut nec obedientiae".

50. F. SUÁREZ, DA 12.2.10.

51. F. SUÁREZ, DM $10.1 \mathrm{ff}$.

52. F. SUÁREZ, DM 10.1.12: "bonum supra ens solum posse addere rationem convenientiae quae non est proprie relatio, sed solum connotat in alio talem natu- 
lect to provide an adequation towards a good, while keeping with the will's freedom. ${ }^{53}$

\section{PRAXIS AS A HABIT}

How can the intellect provide a rule for the will while respecting its freedom of exercise? Suárez's notion of praxis is revealing in this sense: its definition may help to assess the relation between the intellect and the will; its status as a habit provides the framework to understand the peculiar mode of free actions.

In the first regard, the definition of praxis provides a systematical fundament for the intellect-will relation. We have sketched the main order of these faculties, with the intellect providing a rule and the will the exercise:

The intellect is the one that directs the will and even man itself, for the exercise of an operation certainly requires freedom, but the correctness of that operation comes from the intellect. Therefore, we cannot deny that these faculties do bring among themselves a certain order and collaborate mutually, but the will has a bigger dependence on the intellect than the other way around. ${ }^{54}$

More specifically, Suárez works with Scotus in mind in DM XLIV.55 Scotus deals with this question when commenting the Aristotelian notion of praxis in his commentary on Book IX of the Metaphysics; indeed, in a way he is actually re-defining praxis, since he argues

ram habentem naturalem inclinationem, capacitatem, vel coniunctionem cum tali pefectione; unde bonitas dicit ipsam perfectionem rei, connotando praedictam convenientiam seu denotationem consurgentem ex coexistentia plurium".

53. For a thorough study on the bonum see R. DARGE, Suárez' transzendentale Seinsauslegung und die Metaphysiktradition (Brill, Leiden, 2004) $313 \mathrm{ff}$.

54. F. SuÁrEZ, DA 12.XII, q3, 7.

55. On Scotus's influence on Suárez cf. C. GonZÁLEZ AyESTA, Sobre el "escotismo" de Suárez: el caso de la causalidad de la especie, en A. ECHAVARRÍA, J. F. FrancK (eds.), La causalidad en la filosofía moderna (Servicio de Publicaciones de la Universidad de Navarra, Pamplona, 2012) 9-16. 
Aristotle did not conceive the will as a distinct faculty. ${ }^{56}$ The Subtle Doctor distinguishes natural and rational potencies, but he argues that their difference doesn't depend on their possible objects (i.e. that they can act "over this or that object"), but rather in their very acts: "according to the operation through which it elicits the object in such a way or another". ${ }^{57}$ According to Scotus, there are only two ways to elicit an operation. The first way is called "nature"; it consists in "operating in such a way that it can't by itself stop operating unless it is externally impeded". The other way is called "will" (voluntas), and it signifies a potency that "by itself can perform this act or its opposite, and even act or not". ${ }^{58}$

56. As Aristotle had no equivalent notion of the will as a different potency, let alone a superabundant power that can determine itself, Scotus refers the intellect/will difference to their proper acts, and to the acts of the inferior potencies they cause. The intellect's act should then be redirected to the instances in which Aristotle refers to the principle that presents and guides (ostendendo et dirigendo), and the will to the principle that inclines and appetizes (inclinando et imperando). See DuNS SCOTUS, In IX Metaph 15.36: "Responsio: intellectus et voluntas possunt comparari ad actus proprios quos eliciunt, vel ad actus aliarum potentiarum inferiorum in quibus quandam causalitatem habent: intellectus ostendendo et dirigendo, voluntas inclinando et imperando. Prima comparatio est essentialior, patet. Et sic intellectus cadit sub natura. Est enim ex se determinatus ad intelligendum, et non habet in potestate sua intelligere et non intelligere sive circa complexa, ubi potest habere contrarios actus, non habet etiam illos in potestate sua: assentire et dissentire. In tantum quod si etiam aliqua una notitia sit oppositorum cognitorum, ut videtur Aristoteles dicere, adhuc respectu illius cognitionis non est intellectus ex se indeterminatus; immo necessario elicit illam intellectionem, sicut aliam quae esset tantum unius cogniti. Voluntas ad proprium actum eliciendum opposito modo se habet, ut dictum est prius.- Unde isto modo loquendo ponuntur tantum duae productiones in divinis, et quod intellectus est idem principium cum natura.- Secundum hanc primam comparationem non videtur loqui Aristoteles."

57. Duns Scotus, In IX Metaph 15.21: "De primo sciendum est quod prima distinctio potentiae activae est secundum diversum modum eliciendi operationem: quod enim circa hoc vel illud agat (etsi aliquo modo distinguat), aut distinctionem ostendat, non tamen ita immediate. Non enim potentia ad obiectum, circa quod operatur, comparatur nisi mediante operatione quam elicit, et hoc sic vel sic."

58. Duns Scotus, In IX Metaph 15.22: "Iste autem modus eliciendi operationem propriam non potest esse in genere nisi duplex. Aut enim potentia ex se est determinata ad agendum, ita quod, quantum est ex se, non potest non agere quando non impeditur ab extrinseco. Aut non est ex se determinata, sed potest agere hunc actum vel oppositum actum; agere etiam vel non agere. Prima potentia communiter dicitur 'natura', secunda dicitur 'voluntas". 
There is no "cause" for this difference; this is just the way potencies are..$^{59}$ The will is by nature undetermined to any object, and moves towards a specific one according to a "superabundance of sufficiency, which is an illimitation for actuality", ${ }^{60}$ it is an "indeterminate potency that can determinate itself", a potency that is "active, excellent in perfection and power, and not linked to a determined act". ${ }^{61}$ Suárez follows this view, making way for a 'virtual act of the will' so that its self-determination actually means determining itself towards a determinate act.

The intellect's knowledge of opposite is not a sufficient cause for free actions; otherwise, both effects would be produced. The intellect is 'rational' only secundum quid, "insofar as it is a requisite for the act of the rational faculty," ${ }^{2}$ namely, the will. It is the will that allows for external actions, even determining "the intellect according to the causal power it has to operate externally." ${ }^{3}$ What Aristotle calls probairesis, must be understood as referring to the will. ${ }^{64}$

59. Duns Scotus, In IX Metaph 15.24: "Sicut enim effectus immediatus ad causam immediatam comparatur per se et primo et sine causa media - alioquin iretur in infinitum-, ita causa activa ad suam actionem, in quantum ipsam elicit, videtur immediatissime se habere. Nec est dare aliquam causam quare sic elicit nisi quia est talis causa".

60. Duns Scotus, In IX Metaph 15.31: "Responsio: est quaedam indeterminatio insufficientiae, sive ex potentialitate et defectu actualitatis, sicut materia non habens formam est indeterminata ad agendum actionem formae; est alia superabundantis sufficientiae, quae est ex illimitatione actualitatis, vel simpliciter vel quodammodo".

61. Cfr. Duns Scotus, In IX Metaph 15.32 \& 15.34.

62. Duns Scotus, In IX Metaph 15.38.

63. Duns Scotus, In IX Metaph 15.39: "Sequitur voluntas determinans, non sic quod ipsa potentia voluntatis ex se determinata sit ad unum - et per hoc aggregatum ex intellectu oppositorum et voluntate sit unius, ut supra allegatur- sed quod voluntas, quae indeterminata est ad actum proprium, illum elicit et per illum determinat intellectum quantum ad illam causalitatem quam habet respectu fiendi extra".

64. Cfr. Duns Scotus, In IX Metaph 15.40 \& 15.41. "On the other hand, why does he always talk of the intellect and not of the will as a rational faculty, even if he insinuates it, according to what we have said? We could say that the act of the intellect is normally previous to the act of the will, and more noticeable to us. Aristotle often speaks of that which is more manifest, and therefore he says little of the will, even if we can assume from his words that he would have said some things if he had considered it" (In IX Metaph 15.53). We may here acknowledge Rapp's conclusion: even if Aristotle does not explicitly speak of the will, he nevertheless 
Suárez acknowledges the different roles of the intellect (rule) and the will (exercise); still, he mildly reformulates the notion of praxis. First, he acknowledges Scotus's definition: "Praxis is the act of a potency different to the intellect, naturally posterior to intellection, destined by nature to be realized in conformity with right reason so that it may be right." ${ }^{65} \mathrm{He}$ then goes on to say that according to this definition, praxis may also be an act of the intellect if directed by a previous act of the same intellect (n. 24). This would entail that the proper ratio of praxis is the guidance of a faculty in its operation; it would also mean that praxis does not have to refer to a different faculty than the intellect. Thus, the intellect becomes a true rule for praxis. His final definition of praxis is that it is "any human or rational action, insofar as it is directed, or is dirigible or regulable by human reason" ${ }^{66}$ (When the action is dirigible in a moral sense, it is called praxis; when it is dirigible according to art, it is called production. $)^{67}$

Of course, this places praxis again in the realm of the intellect, as the true root of freedom; more specifically, as the disposition to direct rational moral actions. In my opinion, it is precisely this locus - praxis as an intellectual practical habit - what ultimately allows the introduction of ends into human actions. ${ }^{68}$ In this arrangement, praxis can be seen as a habit concerning practical reason, i.e. within the framework of practical truth. This is the proper setting for Suárez's theory of law, and helps to temperate the idea of Suárez's as a "voluntarist".

seems to consider a lot of the necessary components for a theory of the will: "[he] relates the two topics, the topic of the voluntary and the topic of the probairesis by saying that the voluntary is broader than the chosen, i.e. there are cases of the voluntary in which nothing is chosen or, in the terminological sense of boulêsis, wished for. He mentions animals and children who act or do what they are doing voluntarily without being able to terminologically choose it. Furthermore, in the case of adult human beings it happens that they do things spontaneously without considering them beforehand." (C. RAPP, op. cit., 75).

65. F. SUÁREZ, DM 44.13.20.

66. F. SuÁrEZ, DM 44.13.28.

67. Cfr. F. SuÁREZ, DM 44.13.29.

68. T. PINK, Suarez, Hobbes cit., 152: "Suarez's theory of final causation is an attempt to model normative power for the practical sphere; and his theory of free efficient causation is an attempt to model freedom". 
According to Aristotle in bk. VI of the Nichomeachean Eth$i c s$, praxis is an intellectual habit. It is a way of seeing or cognizing things as subject to practical deliberation. Through praxis, we do not consider the order of things as it is, but as objects of action dependent on a contingent will. Since real action is in line with efficient causality, the will's act does not always necessarily follow in reality. But their contingency depends on the will determining itself towards an end, a possible good, provided by the intellect. While the will's exercise is thus safeguarded as the formal ratio of freedom, the provision of a cognized possibility for actions sits at the beginning of actions. Freedom depends then on the intellect's ability to devise courses of action, i.e. of seeing the world as the realm of possibilities: not of things as necessary, but of things as operable. ${ }^{69}$

This final determination comes at the very end of DM XLIV. In section $13 \mathrm{nn} .31 \mathrm{ff}$., Suárez discusses the distinction between theoretical and practical habits of the intellect. In the beginning, Suárez argues against the opinion that divides them based on their material object i.e. that the theoretical habit is about de re non operabile a nobis, and the practical de re operabile. ${ }^{70}$ This is insufficient because we can actually speculate about operable realities. Others take this same objects in a more formal sense (baec distinguunt ex eisdem obiectis formalius sumptis): in this case, a practical science would be the one which actually teaches how to operate with objects. The difference would here be in the end of each habit: "the speculative habit ultimately stops [sistit] in the knowledge of truth, while the practical one tends towards the operation." ${ }^{\prime 1}$ In the end, the material object ends up being determined by the habit's goal. Now a possible question would consider if the goal of the habit is to actually consider an external practical action, or whether it is enough for it to consider operable objects. For example: if an architect learns how to build a house, is his consideration actually practical or is it only so when he is actually designing a house? If the actual opera-

69. Cfr. Aristotle, Eth. Nic. 1139a 5-15.

70. Cfr. F. SuÁREZ, DM 44.13.34.

71. Ibidem. 
tion determined the end of the habit, we would find ourselves with the possibility that "the sole change of intention would turn the one same habit from practical to speculative, and viceversa."72

In the end, Suárez will hold that a practical science, by its own nature, is not constituted by the subject's disposition ("for, even if I were to learn natural philosophy or metaphysics with the intention of making money, or of pleasing my will, that does not of itself make those sciences practical." $)^{73}$ Rather, a science is practical if it "deals by its own nature with operable things insofar as they are operable, so that by itself it eases action; such a science is intrinsically practical." 74 The subject's disposition for action belongs to the "perfectum illum statum scientiae practicae," but even this necessarily "presupposes that the science itself is ordained towards operations or is regulative of operations." 75

The final point of this paper appears in DM 44.13.38. Here Suárez holds, following Aristotle, that the distinction between the practical and the theoretical habit, between the intellect that remains in the truth and the one that is directed towards actions, does not depend on the intent of the will, but "convenes of itself to the intellect $u$ antecedit voluntatem. From here, it turns out that the intellect does not make itself practical by an intention of the will, but it is itself, insofar as it is practical, the one that moves and modifies the will". So in the end, the practical and theoretical intellect "may both elicit their own acts, and it is through them that these are practical or speculative, and not only through the intent of the will."

To sum up: human actions differ from natural or even animal actions insofar as they incorporate ends as such into themselves. The intellect's representational priority sets up the end of an action, while the will elicits the action through its power for self-determination. While the will is not determined in its own exercise by the intellect, a simple voluntarist account of action does not justly represent Suárez's view, as the Doctor Eximius maintains the necessity of

72. F. SUÁREZ, DM 44.13.36.

73. F. SuÁREZ, DM 44.13.37.

74. Ibidem.

75. Ibidem. 
the intellect's acquisition of the good to ground the will's freedom. However, the way the intellect brings about this concept of goodness is not simply a result of its greater cognitive power against that of the interior sense: indeed, it is only insofar as the intellect contemplates operable things as such that the realm of possibilities for action opens up. The consideration of the practical habit as a way of looking at objects (turning them into operabilia) seems therefore to be the critical point that allows the will to relate to its proper object (bonitas, as an object set by the intellect as a rule, i.e. as an object the will can self-determine itself to adequate to) and to desire goods. In other words: the intellect, as capable by praxis of looking into operabilia, is what ultimately allows for the possibility of introducing our own determinate ends into external actions. 
OTROS ESTUDIOS 
